\title{
Bypassing Habeas: The Right to Effective Assistance Requires Earlier Supreme Court Intervention in Cases of Attorney Incompetence
}

\author{
Michael M. O'Hear \\ Marquette University Law School, michael.ohear@marquette.edu
}

Follow this and additional works at: http://scholarship.law.marquette.edu/facpub

Part of the Law Commons

Publication Information

Published as Michael M. O'Hear, Bypassing Habeas: The Right to Effective Assistance Requires

Earlier Supreme Court Intervention in Cases of Attorney Incompetence, 25 Fed. Sent'g Rep. 110 (2012). (C) 2012 by the Regents of the University of California on behalf of the Vera Institute of Justice. Copying and permissions notice: Authorization to copy this content beyond fair use (as specified in Sections 107 and 108 of the U. S. Copyright Law) for internal or personal use, or the internal or personal use of specific clients, is granted by the Regents of the University of California on behalf of the Vera Institute of Justice for libraries and other users, provided that they are registered with and pay the specified fee via Rightslink ${ }^{\circledast}$ on Caliber (http://caliber.ucpress.net/) or directly with the Copyright Clearance Center, http://www.copyright.com.

\section{Repository Citation}

O'Hear, Michael M., "Bypassing Habeas: The Right to Effective Assistance Requires Earlier Supreme Court Intervention in Cases of Attorney Incompetence" (2012). Faculty Publications. Paper 630.

http://scholarship.law.marquette.edu/facpub/630 


\section{Bypassing Habeas: The Right to Effective Assistance Requires Earlier Supreme Court Intervention in Cases of Attorney Incompetence}

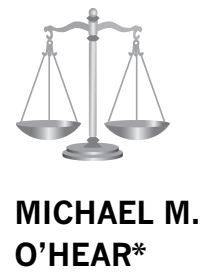

Professor and

Associate Dean for

Research,

Marquette Law

School

Editor, Federal

Sentencing Reporter

Author, Life

Sentence Blog
It is the best of times and worst of times for the right to effective assistance of counsel. Consider two recent, contrasting lines of cases from the Supreme Court. In the first, the Court affirmed that the defendant's right to competent representation extends to plea bargaining and encompasses advice regarding the deportation consequences of a conviction. ${ }^{\text {I }}$ Call this the "expansive-right" line of cases. In the second, the Court brusquely overturned a series of habeas corpus grants on ineffective assistance grounds, emphasizing the high barriers that federal courts must overcome before they may award relief on the basis of unconstitutionally poor representation. ${ }^{2}$ Call this the "narrow-remedy" line of cases.

My purpose in this article is to try to make sense of these two lines of cases and to suggest a path forward. For the past twelve years, beginning with Williams $v$. Taylor, ${ }^{3}$ the Court has been remarkably active in the ineffective assistance area-much more so than at any previous time in the Court's history. Yet, the Court's two dozen decisions since 2000 have a schizophrenic quality, which is exemplified by the two lines of cases noted above. The Court's mixed messages on counsel competency can hardly inspire consistent, vigorous enforcement of this important constitutional right in the lower courts.

Much of the difficulty stems from the peculiarities of federal habeas law. Further invigoration by the Court of the right to effective assistance is thus most likely to come in cases directly from the state courts, which are not subject to habeas restrictions. It is probably no coincidence that the Court bypassed habeas in two of the three expansive-right cases. Indeed, in recent years, the Court has quietly been taking a greater proportion of its ineffective assistance cases directly from the state courts. The Court would do well to continue along this trajectory.

Advocates have an important role to play in this process. Beginning with Williams and continuing through the recent expansive-right cases, the Court has displayed a new willingness to give constitutional force to established defense practice standards, particularly those promulgated by the American Bar Association. ${ }^{4}$ This is a welcome development. But further progress seems unlikely in habeas cases. This reality underscores the need for state postconviction counsel to develop strong factual records and legal arguments in the state courts in support of ineffective assistance claims. Not only do these provide a necessary foundation for compelling certiorari petitions, but they may also encourage the state courts themselves to take the lead in improving ineffective assistance law. Notably, the Supreme Court's recent expansive-right cases relied, in part, on earlier state court decisions-the lower courts led, and the Supreme Court followed.

In developing these points, the article proceeds as follows. Part I sketches the doctrinal backdrop to the expansive-right and narrow-remedy cases, focusing particularly on the tensions in the Court's pivotal Williams decision. Part II describes the two recent lines of cases in more detail. Finally, Part III suggests a path forward, highlighting the potential for habeas bypass to facilitate the Court's clarification and invigoration of the right to effective assistance.

\section{Williams v. Taylor: A Breakthrough for the Right to Effective Assistance, Sort of}

\section{A. State of the Law Before Williams}

The Supreme Court first articulated the test for ineffective assistance claims in 1984 in Strickland v. Washington. ${ }^{5}$ Although Justice O'Connor, writing for the majority, endorsed the principle of a constitutional right to competent representation, her description and application of the legal standards demonstrated little willingness actually to award a new trial or other relief based on allegations of ineffective assistance.

O'Connor's opinion established a now-familiar two-prong test. First, the defendant alleging ineffective assistance must show that his lawyer's performance fell below the standard of "reasonableness under prevailing professional norms." prejudice, that is, "a reasonable probability that, but for counsel's unprofessional errors, the result of the proceeding would have been different." Of course, by placing the burden of demonstrating prejudice on the defendant, Strickland seemingly turned the conventional harmless error test for constitutional violations on its head.

As to the first prong of the Strickland test, Justice O'Connor repeatedly emphasized that "[j]udicial scrutiny of counsel's performance must be highly deferential"8; "the

Federal Sentencing Reporter, Vol. 25, No. 2, pp. IIO-I2I, ISSN I053-9867, electronic ISSN I533-8363. (C) 2012 Vera Institute of Justice. All rights reserved. Please direct requests for permission to photocopy or reproduce article content through the University of California Press's Rights and Permissions website, http://www.ucpressjournals.com/reprintInfo.asp. DOI: IO.I525/fsr.20I2.25.2.IIO. 
court should recognize that counsel is strongly presumed to have rendered adequate assistance and made all significant decisions in the exercise of reasonable professional judgment."9 Although O'Connor recognized that "[p]revailing norms of practice as reflected in American Bar Association standards and the like" could be consulted in the reasonableness analysis, she also made clear that "they are only guides. No particular set of detailed rules for counsel's conduct can satisfactorily take account of the variety of circumstances faced by defense counsel or the range of legitimate decisions regarding how best to represent a criminal defendant." ${ }^{\text {IO }}$ As if to underscore the marginal value of bar standards, O'Connor did not even make passing reference to them in applying her test and finding the performance of defendant David Washington's counsel reasonable. ${ }^{\text {II }}$

Lurking in the background of Strickland was a fear that overly generous standards would "encourage the proliferation of ineffectiveness challenges," which would not only burden the court system but also potentially impair attorney-client relationships and discourage lawyers from taking court-assigned cases. ${ }^{12}$ Then, too, there was the problem that ineffective assistance claims, by their nature, tended to be brought long after trial in collateral attacks on the conviction or sentence (as happened in Strickland itself). ${ }^{\mathrm{I}}$ The close practical association between ineffective assistance claims and collateral review did nothing to make the claims more attractive to the Court. Then-Justice Rehnquist had long and forcefully articulated the view that trials should be the "main event" and not simply a "tryout on the road" for later postconviction proceedings. ${ }^{14}$ Indeed, by the time Strickland was decided, Rehnquist, joined by O'Connor and other habeas skeptics on the Court, had already been engaged for some time in a successful effort to restrict habeas remedies. ${ }^{15}$ Although the Strickland decision itself focused on substantive constitutional rights, it may be appropriate to view Strickland as part of the line of habeas cases that were intended to minimize meddling by federal courts with state court judgments (especially death sentences).

In the decade following Strickland, the Court did nothing to dispel the perception that the ineffective assistance claim was little more than a doctrinal placeholder-something that had to be recognized in principle as a possible basis for postconviction relief in order to prevent the right to counsel from too obviously collapsing into a meaningless formality, but that ought in practice to be discouraged through strong presumptions against the defendant. The Court's initial line of post-Strickland cases culminated with its 1993 decision in Lockhart v. Fretwell. ${ }^{\mathrm{I}}$ In Fretwell, as in Strickland itself, the Court affirmed a death sentence over the defendant's claim that he received ineffective assistance in his capital sentencing proceeding. Although not entirely clear in its import, certain language in Chief Justice Rehnquist's opinion for the majority might be understood to raise the prejudice bar even higher than Strickland had set it. For instance, Rehnquist wrote, "To set aside a conviction or sentence solely because the outcome would have been different but for counsel's error may grant the defendant a windfall to which the law does not entitle him."17

\section{B. The Williams Breakthrough}

After Fretwell, the Supreme Court essentially lapsed into silence on ineffective assistance until Williams, seven years later. Two developments in the interim may have prompted some rethinking on the Court about ineffective assistance, particularly by Justices O'Connor and Kennedy, both of whom had been in the Fretwell majority. First, Congresseither not understanding or not being fully satisfied with the Court's line of anti-habeas cases_adopted a multitude of new statutory restrictions on habeas through the Antiterrorism and Effective Death Penalty Act of 1996 (AEDPA). ${ }^{18}$ These restrictions diminished the practical significance of the Court's independent efforts to pare back habeas, and may have helped to convince O'Connor and Kennedy that they could loosen the reins a bit on the development of the substantive right to effective assistance without fear of a "proliferation of ineffectiveness challenges" at the federal habeas level. Second, a series of highly publicized exonerations of death row inmates in the I990 made more pressing than ever before concerns about the reliability of death sentences and the competence of appointed counsel in capital cases. ${ }^{19}$ Indeed, in the wake of these exonerations, O'Connor herself publicly expressed reservations about the death penalty. ${ }^{20}$

Whatever the reason, Williams-with O'Connor and Kennedy in support-seemed to mark a sea change in the Court's approach to ineffective assistance. ${ }^{2 \mathrm{I}}$ At the most basic level, and in sharp contrast to Strickland and Fretwell, a death row inmate complaining about the quality of his representation at the sentencing phase actually won. In particular, Williams argued that his trial counsel had failed to discover a host of mitigating evidence that might have led to a sentence other than death being imposed. In finding that Williams satisfied both prongs of the Strickland test, the Court squarely rejected the state's (not wholly unjustified) contention that Fretwell had raised the prejudice bar. ${ }^{22}$ Also of note, the Court prominently cited the ABA Standards for Criminal Justice in its holding that counsel's efforts had been unreasonably poor, ${ }^{23}$ suggesting a significantly more important role for such standards than Strickland had done.

Against the backdrop of Strickland and Fretwell, Williams was clearly a big deal. But how big? For those who hoped Williams might point the way to a more broadly invigorated right to effective assistance, three aspects of the case should have been troubling. First, there was the Court's treatment of the AEDPA. Oddly, indeed, Williams had two separate majority opinions. Justice Stevens wrote for one majority on the Sixth Amendment analysis, while Justice O'Connor, joined by Kennedy and the Court's conservative stalwarts (Rehnquist, Scalia, and Thomas), wrote for a different majority on the meaning of the AEDPA. O'Connor and Kennedy were the only justices who were part of both 
majorities, and it seemed almost as if what they gave with one hand, they took away with the other. While they supported the more expansive view of the right to effective assistance of their liberal colleagues, they also supported their conservative colleagues' more restrictive view of the power of habeas courts to provide a remedy for Sixth Amendment violations.

The dispute in Williams turned in particular on the meaning of one provision of the AEDPA, now codified at 28 U.S.C. \2254(d)(I), which has since figured prominently in a long line of post-Williams ineffective assistance cases. This provision prohibits habeas relief for any claim adjudicated on the merits in state court, unless the adjudication "resulted in a decision that was contrary to, or involved an unreasonable application of, clearly established Federal law, as determined by the Supreme Court of the United States." For Justice Stevens and the liberal block, \2254(d)(I) did little more than to codify pre-AEDPA decisional law, leaving intact the ability of federal habeas courts to exercise their independent judgment concerning both pure questions of law and applications of law to fact. ${ }^{24}$ However, for O'Connor, Kennedy, and the conservatives, the two halves of \2254(d)(I) (the "contrary to" and the "unreasonable application of" halves) implied different types of legal tests to be used by habeas courts in reviewing different types of state court decisions, including a new, more deferential form of review for state court applications of law to fact. ${ }^{25}$ As O'Connor put it, “a federal habeas court may not issue the writ simply because that court concludes in its independent judgment that the relevant state-court decision applied clearly established federal law erroneously or incorrectly. Rather, that application must also be unreasonable." ${ }^{26}$

Although the fact that Williams himself won demonstrated that the new test was not impossibly difficult to satisfy, pessimists might have found cause for concern in the Court's indication that there would be some set of cases in which state courts applied Strickland (and Williams) "erroneously or incorrectly," but in which federal habeas courts would be powerless to provide a remedy. This aspect of Williams seems consistent with the idea that O'Connor and Kennedy were interested in providing stronger safeguards for defendants in death penalty cases, but did not want at the same time to open the floodgates for habeas litigation more generally. Indeed, by leaving the meaning of "unreasonable" and the border between the "contrary to" and "unreasonable application of" prongs of \2254(d)(I) quite vague, O'Connor and Kennedy pointed the way to a very fact-intensive, case-specific jurisprudence; whether intentionally or not, this approach preserved wide discretion for the Court in future cases to overturn the most troubling death sentences without creating precedent that could be readily used by other habeas petitioners.

This leads into the second cause for concern with Williams: the fact that it was a capital case. Although not voiced in Williams itself, the "death is different" theme had been sufficiently strong in the Court's jurisprudence as to make it unwise ever to assume that constitutional principles developed in capital cases would migrate swiftly to noncapital cases. To some extent, the Court allayed this concern the very next year in Glover v. United States, in which the Court, citing Williams, held that the incorrect calculation of a defendant's sentence under the federal sentencing guidelines constituted "prejudice" under Strickland. ${ }^{27}$ At the same time, the Court made clear that its decision was premised on the determinate, nondiscretionary nature of the federal sentencing system then in place, ${ }^{28}$ which tended to blur the distinction between a sentencing proceeding and a conventional criminal trial on guilt or innocence (a blurring that also existed in capital $\operatorname{cases}^{29}$ ). Left unanswered in Glover was whether and to what extent the more aggressive approach of Williams to the review of counsel's performance would carry over into areas involving more discretion, especially plea bargaining and traditional sentencing. Moreover, Glover dealt only with the prejudice prong of Strickland, and expressly left open that possibility that the performance analysis might be less rigorous if what was at issue was "merely" a few additional months of imprisonment. ${ }^{30}$ Finally, since Glover emerged from a federal prosecution, the special restrictions associated with habeas review did not apply; the analysis might conceivably have looked rather different had \2254(d)(I) governed.

A third source of concern was that the Williams Court did not expressly limit or modify anything in Strickland, despite the obvious tension between the cases; indeed, Williams purported to be nothing more than a straightforward application of the principles announced in Strickland. The Court may have felt itself hemmed in by $\ 2254$ (d)(I) and related pre-AEDPA decisional law; a habeas case was not a proper platform for granting relief on the basis of new legal principles. Yet, whether or not the Court had this end in view, the failure to limit or distinguish Strickland (which, after all, dealt with the very same sort of claim that counsel should have done more to develop mitigation evidence) only enhanced the discretion the Court had implicitly reserved for itself through its vague definition of "unreasonable." In future habeas cases, if the Court were inclined to grant relief, Williams could be drawn on freely-since there was nothing "new" in the decision, there was no retroactivity bar to its use-but if the Court were inclined to go the other direction, then Strickland could be emphasized as the controlling precedent. ${ }^{3 \mathrm{I}}$

\section{Williams' Aftermath: The Court's Schizophrenic Jurisprudence, 2000-2009}

Given the ambiguities and conflicting agendas embodied in the Williams majority opinions, it should be no surprise that the Court's subsequent ineffective assistance decisions would display a schizophrenic character. In the first place, there seemed a basic divide between the Court's treatment of ineffective assistance claims in capital and noncapital cases. In the three noncapital cases between 2003 and 2009 (all arising in habeas), the Court decided in favor of 
the state, noting in each case the deference required by $\int 2254(\mathrm{~d})(\mathrm{I}) \cdot{ }^{32}$ Indeed, the Court signaled quite clearly that it did not think the cases were even close: two of the three were decided without argument via unanimous per curiam opinions, and the third was also decided unanimously. If Williams represented a breakthrough for defendants, that breakthrough plainly did not extend to noncapital cases.

In the capital cases, by contrast, defendants had at least a fighting chance of success. The Court, however, did not follow a consistent path. Williams figured prominently in these decisions, but sometimes it was the O'Connor opinion that was emphasized (establishing deferential review under $\left.\int 2254(\mathrm{~d})(\mathrm{I})\right)$, and other times it was the Stevens opinion (overturning the death sentence based on ineffective assistance). In the former cases, the state won; in the latter, the defendant. If O'Connor and Kennedy really did intend through Williams to create a great deal of flexibility for the Court to review death sentences on a case-by-case basis, they plainly succeeded.

Consider, for instance, Bell v. Cone, ${ }^{33}$ the Court's next ineffective assistance decision after Williams and Glover. Like Williams, Cone argued that his lawyer failed to present important mitigating evidence at sentencing. However, the Court's discussion of Williams was limited entirely to the O'Connor opinion and its interpretation of $\int 2254(\mathrm{~d})(\mathrm{I}) \cdot{ }^{34}$ When the time came for the Court to perform its Sixth Amendment analysis, it was as if Williams did not exist: the Court made no effort to distinguish Williams on the facts, did not even mention the ABA standards, and ultimately relied on Strickland's "strong presumption" that defense counsel's performance was reasonable. ${ }^{35}$ The Court's decision later that year in Woodford $v$. Visciotti was in much the same spirit. ${ }^{36}$

But the following year, in Wiggins v. Smith, ${ }^{37}$ the Court proved that the Stevens opinion in Williams had been no fluke. Once again, the claim was that counsel had failed to investigate and present important mitigating evidence. However, Williams was no longer treated as merely an AEDPA case; rather, the Court observed, Williams was "illustrative of the proper application of [the Strickland] standards." ${ }^{8}$ The Court particularly noted Williams' use of the ABA standards, and invoked those same standards in finding that Wiggins' counsel had failed to render reasonably competent representation. ${ }^{39}$ The Court also looked to Williams with respect to the prejudice prong, pointedly noting that Wiggins' prejudice case was even stronger than Williams' had been. ${ }^{40}$ Although the Court insisted that Williams "made no new law" in the ineffective assistance area, ${ }^{4 \mathrm{I}}$ it is clear that the Wiggins opinion would have looked quite different had Williams not been available to draw on. And now it was the turn of Bell and Woodford to disappear down the memory hole.

In the years following Wiggins, the Court continued to go back and forth in the capital cases, with several decisions drawing sharply worded dissents-in marked contrast to the consensus prevailing in the noncapital cases. Defendants scored victories in Rompilla v. Beard (2005) ${ }^{42}$ and
Porter v. McCollum (2009), ${ }^{43}$ both of which involved claims like Williams and Wiggins of failure to adequately investigate sentencing issues, and both of which invoked ABA standards. But defendants making similar claims lost in Schriro v. Landrigan (2007), ${ }^{44}$ Bobby v. Van Hook (2009), ${ }^{45}$ and Wong v. Belmontes (2009)..$^{4}$ Kennedy and O'Connor (until she left the Court in 2006) continued to serve as the fulcrum in this line of cases, as they had in Williams; with the single exception of Kennedy's dissenting vote in Rompilla, they were always part of the majority. Whether they led the Court in a coherent or predictable fashion is less clear. Although it is possible that distinctions might have been offered to justify each of the decisions relative to precedent, the Court rarely made much effort to do so. Rather, it seemed that with each new decision, contrary precedent was simply ignored. Perhaps this had something to do with the uncertain status of precedent under \2254(d)(I); or with a desire to preserve flexibility for future cases; or with the difficulties of cobbling together a majority around a single, cohesive approach to ineffective assistance. Whatever the reason, when reviewing the whole line of ineffective assistance decisions from 2000 to 2009 , lower courts might understandably have felt that the guidance they were receiving was much less than clear.

\section{Making Sense of the Expansive-Right and Narrow- Remedy Cases}

In this Part, I will carry the story from 2010 to the present (20I2), a time period that saw the Court dramatically intensify its engagement with ineffective assistance issues, even relative to 2000-2009, which was itself a relatively busy period. First, I will describe the expansive-right cases and then move to the narrow-remedy line.

A. Expansive-Right Cases: The Camel Enters the Tent I suggested above that it may be helpful to think about Williams and its progeny as reflective of a more general heightening of concerns on the Court regarding the death penalty in the late I990s and early 2000s. Certainly, this view is consistent with the marked differences we have seen in the way the Court handled capital and noncapital cases from 2000 to 2009 . However, the distinction seemed to break down after 2009, with the expansive-right cases constituting a migration of Williams' more robust version of the Strickland right, and particularly the reliance on formal professional practice standards, from the capital to the noncapital context. In retrospect, Williams now looks like the proverbial camel putting its nose in the tent.

First, in Padilla v. Kentucky (2010), the Court addressed the case of a defendant whose lawyer had incorrectly advised him regarding the deportation consequences of a guilty plea. ${ }^{47}$ The Court rejected the contention that this sort of advice lay categorically beyond the protection of the Sixth Amendment and held that Padilla's lawyer had indeed violated Strickland's performance prong. In so doing, the Court invoked the line of capital cases, including Williams and Wiggins, in which ABA standards had been used, and 
then drew on ABA standards, National Legal Aid and Defender Association guidelines, and other professional norms in support of its conclusion that defense counsel must advise of deportation consequences, at least when such consequences are clear. ${ }^{48}$ With that, the camel was in the tent. And gone were the days of easy consensus on ineffective assistance issues in noncapital cases: two justices dissented, and two concurred in judgment only.

Rounding out the expansive-right cases were two decided on the same day in March 20I2. In Missouri v. Frye, the Court held that the Strickland performance prong was satisfied when a lawyer failed to communicate a plea offer to the defendant before the offer expired. ${ }^{49}$ ABA standards and state rules of professional responsibility figured prominently in the analysis. ${ }^{50}$ Meanwhile, in Lafler $v$. Cooper, the Court held that Strickland's prejudice prong was satisfied when counsel's mistaken advice regarding a plea offer led to the rejection of a favorable plea deal..$^{5 \mathrm{I}} \mathrm{Put}$ together, Frye and Lafler constitute the Court's clearest indication to date that the right to effective assistance extends in a meaningful way to plea bargaining.

The sequence of Sixth Amendment cases from Williams to Frye and Lafler seems to parallel a contemporaneous line of Eighth Amendment cases. The line began in 2002 with Atkins $v$. Virginia, in which the Court-also in the spirit of intensifying its oversight of the death penalty-banned capital punishment for the mentally retarded..$^{52}$ Building on Atkins, the Court then prohibited capital punishment for juveniles three years later in Roper v. Simmons. ${ }^{53}$ Atkins and Roper represented an even more dramatic breakthrough for defendants in the Eighth Amendment area than Williams had in the Sixth, for both decisions expressly overturned recent Supreme Court precedent. Yet, as with the Sixth, the Eighth Amendment jurisprudence looked very different in capital and noncapital cases. Indeed, between Atkins and Roper, the Court rejected Eighth Amendment challenges to two very long noncapital sentences imposed under California's notorious Three Strikes law. ${ }^{54}$ Finally, the Eighth Amendment revolution spread to noncapital cases in 2010, the same year as Padilla, when the Court banned life without parole for most juveniles in Graham v. Florida. ${ }^{55}$ In Graham, the Court for the first time in a noncapital case used the methodology it had developed for addressing Eighth Amendment challenges to capital sentences. ${ }^{56}$ The camel entered the tent.

In the Eighth Amendment cases, the justices have broken down along the same ideological lines as in the Sixth Amendment sequence from Williams through Frye and Lafler, with O'Connor (until 2006) and Kennedy almost always in the majority. Moreover, in the Eighth Amendment cases, the Court has also looked for guidance to what we might think of as a relevant set of practice norms. In the Sixth Amendment cases, when reviewing the constitutionality of lawyer performance, the Court has relied on attorney practice norms; in the Eighth Amendment cases, when reviewing the constitutionality of state sentencing "performance," the Court has looked to the norms of other states and other nations. In both lines of cases, then, the Court has treated constitutional law as an open, evolutionary system, which has caused not a little consternation among the Court's formalists, who prefer an unchanging, hermetically sealed system in which meaning is derived from a fixed body of source materials (constitutional text, historical documents from the ratification time period, and perhaps subsequent judicial precedent). ${ }^{57}$

In any event, we might wonder why the Court has in both the Sixth and the Eighth Amendment contexts advanced jurisprudential breakthroughs from the capital to the noncapital cases. As a practical matter, this largely becomes a question of why Kennedy has seemingly embraced more robust constitutional regulation of noncapital cases. It is possible that at some point Kennedy began to focus in a new way on the extraordinary harshness of noncapital sentences in the United States. Perhaps the Three Strikes cases even had something to do with that. Although Kennedy voted with the majority in both cases to uphold the challenged sentences, just five months later he delivered an impassioned and much-noted condemnation of American sentencing and corrections practices in an address to the American Bar Association. ${ }^{5}$ Some of his comments even seemed to suggest, albeit obliquely, some misgivings about the Three Strikes decisions. ${ }^{59}$ Kennedy seemed especially troubled by inflexibility in American punishment: by mandatory minimum sentences at the front end and by an unwillingness or inability on the back end to provide early release opportunities for offenders who were truly rehabilitated. ${ }^{60}$ This same concern with inflexible punishment quite overtly animated Kennedy's majority opinion in Graham, which established that most juvenile offenders must be given a parole opportunity, but may also have been an important part of the subtext in Padilla, which dealt with an automatic deportation rule, and in Lafler, where counsel's poor advice caused the defendant to become subject to a mandatory minimum sentence of 185 months. ${ }^{6 \mathrm{I}}$

A heightened interest in noncapital cases across the 2000s might also follow from the steadily declining salience of capital punishment in the United States. The annual number of executions peaked at 98 in I999, and then dropped in eight of the next eleven years, standing at only 46 in $2010 .{ }^{62}$ Similarly, the number of new death sentences peaked at 3I5 in 1996 , then fell in ten of the next fourteen years, reaching only Io4 in $2010 .{ }^{63}$ As concerns regarding arbitrary administration of the death penalty grew less pressing, it would seem natural for reformminded advocates and jurists to pay greater attention to injustices in noncapital cases.

Of course, it may be that no single concern or agenda really links Graham, Padilla, Frye, and Lafler. It may be a coincidence that these four cases (as well as two others taking an expansive and arguably unexpected view of Eighth Amendment rights in the noncapital context, Miller $v$. Alabama $^{64}$ and Brown v. Plata ${ }^{65}$ ) were all decided over a three-year period. Whether intentionally linked or not, 
however, the cases do reflect a distinctive brand of legal realism-a certain willingness to adapt constitutional doctrines to make individual rights meaningful in light of contemporary knowledge and circumstances, even at the expense in some cases of blurring established capital/ noncapital distinctions.

\section{B. Narrow-Remedy Cases: Circumscribing the Role of the Lower Federal Courts}

At the same time that the Court seemed to be taking an uncharacteristically expansive view of Strickland rights in noncapital cases, it also acted to tighten the restrictions of $\int 2254(\mathrm{~d})(\mathrm{I})$ on the power of federal habeas courts to remedy Strickland violations. Consider, for instance, Harrington $v$. Richter (20II), in which the Court overturned a habeas grant by the Ninth Circuit. ${ }^{66}$ At one level, this decision might simply be written off as another in the line of post-Williams noncapital cases rejecting habeas relief on the basis of $\int 2254(\mathrm{~d})(\mathrm{I})$. In fact, none of the liberal justices bothered to dissent or otherwise object to the Court's treatment of $\int 2254(\mathrm{~d})(\mathrm{I})$. On the other hand, it may be significant that Harrington was the Court's first ineffective assistance case after the retirement of Justice Stevens, who had authored

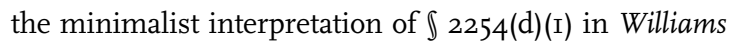
and then proven himself the Court's most consistent supporter of habeas petitioners making ineffective assistance claims. Stevens was the justice most likely to object to any further tightening of $\ \mathbf{2 2 5 4}(\mathrm{d})(\mathrm{I})$, and there were indeed several aspects of Harrington that might have given him pause.

First, there was the Court's palpable dissatisfaction with the Ninth Circuit's decision: the Court's opinion was not simply a reversal of the lower court, but a rebuke. In the opinion's very first paragraph, for instance, the Ninth Circuit was said to have committed "clear error" and shown "disregard" for "sound and established principles." 67 Later, the Court accused the Ninth Circuit of "all but ignor[ing] the only question that matters under $\int 2254(\mathrm{~d})(\mathrm{I}) . " 68$ Through such strong language, the Court seemed intent on amplifying its message that habeas courts must be considerably more deferential to state court decisions than the Ninth Circuit had been.

Second, the Court held that $\ 2254$ (d)(I) deference is required even when the state court gives no reasoning for its decision. $^{69}$ The California Supreme Court had rejected Richter's Strickland claims in a one-sentence summary order. Since $\ 2254$ (d)(I) mandates deference only to a statecourt "adjudicat[ion] on the merits," whether the California Supreme Court's cursory "decision" qualified was a fair question. However, the Supreme Court held that it did, thereby effectively extending $\int 2254$ (d)(I) to the summary orders that have become such a common part of appellate practice in some jurisdictions.

Finally, the Court reiterated and elaborated at length on some brief observations made two years earlier, almost in passing, in Knowles v. Mirzayance. ${ }^{70}$ Read for all it was worth, this language from Harrington seemed practically to raise a categorical bar to habeas relief for Strickland claims. What Knowles suggested, and Harrington elaborated on, was that $\ 2254(\mathrm{~d})$ (I) and Strickland have synergistic effects; considered together, the relevant legal standards raise a nearly insurmountable barrier to relief.

Indeed, merely standing alone, \2254(d)(I) seemed a higher bar in Harrington than even O'Connor had envisioned in her opinion in Williams. Here is how the Harrington Court characterized the test for $\int 2254$ (d)(I)'s "unreasonable application" prong:

Under $\int 2254(d)$, a habeas court must determine what arguments or theories supported or, as here, could have supported, the state court's decision; and then it must ask whether it is possible fairminded jurists could disagree that those arguments or theories are inconsistent with the holding in a prior decision of this court. ...

$\cdots$

If this standard is difficult to meet, that is because it was meant to be. As amended by the AEDPA, $\int 2254(\mathrm{~d})$ stops short of imposing a complete bar on federal court relitigation of claims already rejected in state proceedings. It preserves authority to issue the writ in cases where there is no possibility fairminded jurists could disagree that the state court's decision conflicts with this Court's precedents. It goes no farther. Section 2254(d) reflects the view that habeas corpus is a "guard against extreme malfunctions in the state criminal justice systems," not a substitute for ordinary error correction through appeal. As a condition for obtaining habeas corpus from a federal court, a state prisoner must show that the state court's ruling on the claim being presented in federal court was so lacking in justification that there was an error well understood and comprehended in existing law beyond possibility for fairminded disagreement. $^{7 \mathrm{I}}$

Other than a brief snippet borrowed from an old (preAEDPA) concurring opinion, all of this super-deferential verbiage was new in Harrington, and seemed quite close to a test that O'Connor had expressly rejected in her Williams opinion. $^{72}$

In any event, conceived in these terms, the $\int 2254$ (d)(I) standards interacted in two important ways with the ineffective assistance standards. First, since Strickland had declared that judicial review of counsel's performance itself had to be "highly deferential," review of a state court's denial of an ineffective assistance claim must be "doubly" so. ${ }^{73}$ Second, because the Strickland test was cast in general terms like "reasonableness," deference under \2254(d)(I) had to be all the greater ${ }^{74}$; as had been established in earlier cases, "[t]he more general the rule, the more leeway courts have in reaching outcomes in case-by-case determinations."75

Decided on the same day as Harrington, Premo v. Moore was in much the same spirit, and indeed quoted Harrington 
at length in discussing the governing legal standards. ${ }^{76}$ What was different about Premo was that the challenge to counsel's performance alleged an over-hasty guilty plea, not a botched trial strategy. Premo thus gave the Court an opportunity to expound on the Strickland standards as they relate to plea bargaining. And, in marked contrast to what the Court would say on this topic the very next year in Lafler and Frye, the Court in Premo suggested a special, heightened deference to counsel's plea-bargaining efforts, especially in habeas cases. ${ }^{77}$

The Court took its stingy approach to habeas relief a step or two further in Cullen v. Pinholster, ${ }^{78}$ which involved the same sort of claim of deficient performance in a capital sentencing proceeding on which the Court had granted relief in Williams, Wiggins, and Rompilla. Cullen was notable for at least two reasons. First, the Court held that, for purposes of $\int 2254(\mathrm{~d})(\mathrm{I})$, habeas review was limited to the record developed in the state court. ${ }^{79}$ This was, of course, consistent with Harrington's view that habeas relief was only for "extreme malfunctions in the state criminal justice systems," and not merely for saving defendants from substantively incorrect or unjust judgments-if a defendant's habeas claim in federal court was largely based on new evidence, no matter how compelling the evidence was, the state court's failure to grant relief on the claim could hardly be regarded as a systemic malfunction.

Second, the Court's cavalier treatment of the factually similar cases of Williams, Wiggins, and Rompilla and their methodology suggests an almost implicit reversal of the precedent. Rather than engaging in a close comparison of the cases, the Cullen majority fell back on Strickland's mandate of deference, resistance to general rules or guidelines, and insistence that each case by considered on its own. ${ }^{80}$ Indeed, while the dissent emphasized that counsel's performance violated ABA guidelines, ${ }^{8 \mathrm{I}}$ the majority did not bother even to cite or discuss the guidelines, but instead suggested that the benchmark for attorney performance should not be formal, national standards, but rather local practice norms ${ }^{82}$ - proof of which would, of course, be much more difficult for defendants. At a minimum, Cullen raised serious questions about whether the days of a more relaxed approach to $\int 2254$ (d)(I) in capital cases were at an end.

\section{Reconciling the Cases}

One way to make sense of the two lines of cases, expansiveright and narrow-remedy, would be to focus on the procedural posture of the cases. All of the narrow-remedy cases reached the Supreme Court via federal habeas, and were

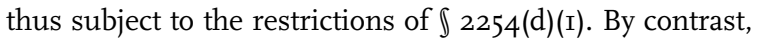
two of the three expansive-right cases bypassed habeas, permitting the Court to engage in less deferential review. We might accordingly draw the lesson that ineffective assistance claims will fare much better outside the habeas setting than within, which would be quite consistent with what the Court itself indicated through the double-deference language in Harrington.
I think there is something to this view of the cases, although it does beg a couple of questions. First, what about the more flexible approach to $\int 2254(\mathrm{~d}(\mathrm{I})$ that was exemplified by Williams, Wiggins, and Rompilla: has the Court decisively rejected that approach, and, if so, why? I have suggested that Williams, Wiggins, and Rompilla might best be understood as part of a broader effort by the Court in the early and mid-20oos to subject the death penalty to more rigorous constitutional regulation. From that perspective, Harrington and Premo may be distinguished because they were noncapital cases. Cullen, though, does not fit the pattern. Perhaps Cullen is a sign that, as the death penalty has diminished in importance, the Court will no longer treat capital and noncapital cases differently under $\ 2254$ (d)(I). Or perhaps it is an indication that the Court's enhanced Eighth Amendment restrictions on capital punishment have obviated the perceived need for particular Sixth Amendment protections. Or perhaps it is a reflection of personnel changes on the Court; especially decisive may be the departures of O'Connor, a key swing voter in Williams, Wiggins, and Rompilla, and Stevens, the Court's strongest proponent for ineffective assistance claims in habeas. Or perhaps Cullen was simply a fluke, or another instance, like Bell v. Cone, of the Court's erratic path even in the capital cases.

Second, what about Lafler? This is the one case in the recent expansive-right line that does not fit the pattern; it arose in habeas, and was formally subject to $\ 2254$ (d)(I). The Lafler Court's own solution to the $\$ 2254$ (d)(I) dilemma was to rely on the "contrary to" prong of the statute, rather than "unreasonable application," which had been the prong at issue in the narrow-remedy cases. More specifically, the Court held that the state court's decision in Lafler was contrary to Strickland because the state court had focused on whether the defendant's plea was knowing and voluntary, rather than on the Strickland test itself, and "made an irrelevant observation about counsel's performance at trial and mischaracterized respondent's claim as a complaint that his attorney did not obtain a more favorable plea bargain." 83 But the Court's expansive approach to "contrary to" in Lafler seems perverse in light of Harrington. ${ }^{84}$ Under Harrington, a state court that provides no explanation at all for its decision gets full $\ 2254$ (d)(I) deference, whereas, under Lafler, a state court that actually supplies reasoning for its decision-which would seem to be something the Supreme Court should encourage-runs the risk of saying something that the Court will construe to be contrary to one of its precedents. Although Harrington and Lafler may be able to coexist in some hyper-formal sense, the two are functionally at odds with one another, leaving it quite uncertain whether we will continue to see Lafler's expansive approach to the "contrary to" prong with any consistency in the future. In truth, Lafler may have simply ridden the coattails of Frye; between these two mirror-image cases decided on the same day, the Court was attempting to sketch a comprehensive approach to the application of Strickland to plea bargaining, and the Court may have been 
anxious to avoid muddying the waters by rigorously applying $\int 2254(\mathrm{~d})(\mathrm{I})$.

In sum, the cases can be reconciled from a formal doctrinal standpoint, albeit not without a certain amount of tension. There is, however, another, more subtle theme that ties all of the cases together: a distinct reluctance to give convicted defendants new trials, even when attorney performance is found inadequate. The narrow-remedy cases most obviously reflect this reluctance, but it is also apparent in the expansive-right cases. Padilla, for instance, only addressed the performance prong of Strickland, and pointedly declined to decide whether the defendant could demonstrate prejudice. ${ }^{85}$

Meanwhile, in Frye, the Court not only remanded the case for the state court to make a prejudice determination, as in Padilla, but also went out of its way to indicate that the defendant would face a difficult hurdle on this score. When counsel's incompetence caused the defendant to lose a plea deal, the Court held, the defendant's prejudice burden includes showing "a reasonable probability the plea would have been entered without the prosecution canceling it or the trial refusing to accept it." 86 This was a real problem for Frye because he had been arrested on a new offense shortly after his plea offer expired. Even without such an occurrence, however, it is not entirely clear how a defendant would persuasively demonstrate that a judge would have accepted a plea deal, and one imagines a strong temptation for trial judges - reluctant to reopen cases they had thought resolved - to deny that they would have accepted the deal.

Finally, Lafler demonstrated that there was yet another barrier to relief, even if a defendant could get around $\int 2254(d)(I)$ and satisfy both prongs of Strickland. The defendant in Lafler managed to do all of these things, but nonetheless faced a remand to determine the remedy, and the Court seemed to leave open the possibility that he might get much less than he wished-indeed, perhaps nothing at all. In the Court's view, the question of remedy required a balancing of competing interests:

Sixth Amendment remedies should be tailored to the injury suffered from the constitutional violation and should not unnecessarily infringe on competing interests. Thus, a remedy must neutralize the taint of a constitutional violation, while at the same time not grant a windfall to the defendant or needlessly squander the considerable resources the State properly invested in the criminal prosecution. ${ }^{87}$

With these concerns in mind, the Court divided lostplea-deal cases into two categories. First, when the defendant lost an opportunity to plead guilty to a lesser charge, then the prosecution would be required to reoffer the plea deal. However, this would not guarantee that the defendant would actually benefit; "Once [the plea deal has been offered again], the judge can then exercise discretion in deciding whether to vacate the conviction from trial and accept the plea or leave the conviction undisturbed." 88 In the second category, where the lost deal related only to sentencing and not to counts of conviction, the remedy would be a resentencing. However, in this category, too, the judge was granted wide discretion; the judge could choose among "the term of imprisonment the government offered in the plea, the sentence [the defendant] received at trial, or something in between." 89 Moreover, with respect to both categories, the Court indicated that the judge's exercise of discretion could take into account a defendant's earlier expressed unwillingness to take responsibility for the offense (which would arguably be present any time a lost plea deal has resulted in the defendant going to trial) and "any information concerning the crime that was discovered after the plea offer was made." 90 This seems to give the trial judge ample basis in most cases to reaffirm the original judgment without fear of appellate reversal. Again, one imagines a general inclination to do just that.

\section{A Path Forward}

I've suggested two possible accounts of the recent ineffective assistance cases. In one account, habeas bypass plays a key role. The Court really cares about $\ 2254(\mathrm{~d})(\mathrm{I})$ and the underlying policy choices it embodies; ineffective assistance claims in habeas are thus highly unlikely to find success-perhaps now even in capital cases as much as in noncapital cases. Outside of habeas, though, the Court is slowly bringing the more rigorous approach to evaluating attorney performance that it developed in the capital realm to a much wider body of cases.

In the alternative account, the Court's real interest lies in keeping a tight lid on new trials without entirely excluding the possibility of relief in the most extreme cases. In the habeas setting, \2254(d)(I) is simply a convenient tool for either denying relief or couching a grant of relief in such terms that it will have little impact as precedent on other cases. But, outside of habeas, the Court has plenty of other tools to accomplish the same ends: the malleable performance and prejudice tests from Strickland, the selective use of what is now a large and very mixed bag of precedent, and Lafler's highly discretionary, case-specific approach to remedy.

As a purely explanatory matter, there is probably a certain amount of truth to both accounts. Indeed, how much 』2254(d)(I) really matters probably varies from justice to justice and case to case.

In any event, in this section, I move from the explanatory to the prescriptive. The argument proceeds in three parts. First, I contend that the Court, in trying to make sense of its precedent, should embrace the first accounthabeas bypass makes a difference. Second, the Court should stop taking ineffective assistance cases out of habeas, and instead focus on using habeas-bypass cases to clean up some of the mess that ineffective assistance doctrine has become. Finally, in appropriate habeas-bypass cases, the Court should decisively reject the mushy, indiscriminately deferential performance test of Strickland and instead develop clearer, more rigorous standards in light of widely accepted national practice norms. These are not the 
only developments that would make for better ineffective assistance law, but they seem a feasible path forward in light of the Court's most recent decisions.

\section{A. Habeas Bypass Matters}

From a formalist perspective, it seems simple enough that habeas bypass should matter. After all, Congress adopted a statute, the AEDPA, that imposes particular standards for habeas claims, and it is conventionally assumed that where Congress legislates, Congress intends to effectuate change. This was the thrust of O'Connor's opinion in Williams. To take the contrary view-that habeas and habeas bypass are all the same-would be more in the spirit of the Stevens opinion, which, of course, failed to secure a majority. And a host of post-Williams decisions reaffirms, at least at a rhetorical level, that the AEDPA did indeed make a difference, culminating in the "double-deference" formula of Harrington.

To be sure, the AEDPA - a poorly drafted, hastily adopted statute-seems unusually ill-suited for formalist analysis. ${ }^{9 \mathrm{I}}$ However, even beyond an imagined legislative intent, there are other good reasons to think that habeas bypass should matter.

Indeed, prior to the AEDPA, the Court had for at least two decades embraced the notion that habeas should be regarded as a unique procedural setting with particularly high barriers to relief. Consider, for instance, the plurality opinion in Teague v. Lane, which established that a habeas petitioner may not normally take advantage of new rules of criminal procedure adopted by the Supreme Court after the petitioner's conviction became final. ${ }^{92}$ Teague highlighted two interests in support of this rule: finality and comity. Neither interest, however, pushes as strongly against relief when the Court bypasses habeas.

Finality interests, for instance, grow stronger the further a case moves from the original trial and conviction. As time wears on, it becomes increasingly burdensome for the state to mount a fresh prosecution if a new trial is ordered, and it becomes decreasingly likely that a fresh trial would produce reliable results. Evidence will be lost, witnesses will disappear or become incapacitated, memories will fade, and so forth. The flipside, though, is that the Supreme Court should have considerably less fear of delivering a windfall to a defendant or an unfair burden to the state when it awards relief prior to federal habeas proceedings.

Comity interests-that is, the federal system's interest in showing respect for state courts and state law-may also be less compelling in the habeas-bypass setting. First, when \2254(d)(I) does not apply, the Court can overturn a state decision as incorrect without labeling it unreasonable, which may take some of the sting out of the reversal. Second, when the Court does overturn a conviction in habeas, that decision provides at least marginal encouragement for lower federal courts also to grant relief in other cases notwithstanding $\int 2254(\mathrm{~d})(\mathrm{I})$, and one imagines that reversals by the lower federal courts-especially single-judge district courts and three-judge circuit panels-are perceived as a much greater affront by state courts than reversals by the larger and more prestigious Supreme Court. By contrast, when the Court grants relief in a habeas-bypass case, $\int 2254(\mathrm{~d})(\mathrm{I})$ is not weakened and indeed remains as a barrier for lower federal courts to treat the new Supreme Court decision as controlling precedent in other habeas cases.

In sum, the force of finality and comity interests seems attenuated in habeas-bypass cases, which supports treating them differently.

\section{B. No More Ineffective Assistance Cases in Habeas} Reviewing the whole line of cases from Williams through Lafler, one cannot avoid the sense that the Court has veered unpredictably back and forth in its openness to ineffective assistance claims in habeas. The Court's approach has created a mass of poorly reconciled precedent, with many of the holdings based on fact-intensive, case-specific analysis. There seems little clear guidance here for lower courts.

Future habeas cases are unlikely to clarify matters. Section 2254(d)(I) and Teague prevent the Court from developing new rules in habeas cases in support of relief; if the Court wants to grant relief, it must act as if relief follows inexorably from the vague mandates of Strickland itself. The result is simply a piling on of more inconsistent precedent.

In any event, the project of clarifying the habeas standards hardly seems worth the effort. When the Court decides a habeas-bypass case, it tells us what the Constitution means. Its words reverberate throughout the legal system, providing guidance to all courts at all levels. But, when the Court decides a habeas case, it speaks not to the meaning of the Constitution, but to the much more obscure question of whether a particular interpretation or application of the Constitution was unreasonable at the time it was made in light of then-existing Supreme Court precedent (which may well have been subsequently superseded). The Court speaks to federal habeas courts, not the legal system as a whole, and the odd, AEDPA-based terminology it uses seems as likely to confuse as to illuminate matters in the state courts. Rather than spending its time trying to give more precise content to habeas-specific concepts like Harrington's double deference-a project that seems likely to conjure images of angels and heads of pins-the Court would do better to focus on elucidating the basic right to effective assistance itself.

Cullen, moreover, has largely undermined the strongest practical reason for the Court to wait to take ineffective assistance cases until after lower-court habeas proceedings. In principle, federal district courts might have had a useful role to play in conducting evidentiary hearings on disputed factual matters. However, Cullen eliminates this role in cases subject to $\int 2254(\mathrm{~d})(\mathrm{I})$, since the decision under this section must now be made based solely on the state court record. With the record frozen when state court proceedings end, the Supreme Court gains nothing by waiting for lower-court proceedings in habeas.

To be sure, the Court may be concerned about intercircuit disparities in habeas cases, and particularly that 
some circuits will grant habeas relief too liberally without Supreme Court oversight. It is important to remember, though, that the AEDPA and pre-AEDPA decisional law impose a host of additional constraints on habeas beyond $\int 2254(\mathrm{~d})(\mathrm{I})$. What I propose is only that each circuit be left to its own devices in deciding how $\int 2254$ (d)(I) applies to Strickland claims. It seems unlikely that any more than a few isolated defendants would manage to evade the many other limitations on habeas relief in order to benefit from a possible loosening of $\ 2254(\mathrm{~d})$ (I) limitations in some circuits. The most comprehensive empirical study of postAEDPA habeas found an effective relief rate of $0.64 \% .{ }^{93}$ Given what appears to be a powerful, pervasive disinclination among federal courts to grant habeas relief, subtle changes in the Supreme Court's role hardly seem likely to throw open the prison doors. This seems all the less likely in an area in which the Court's role has been as equivocal as it has with respect to the application of $\int 2254$ (d)(I) to Strickland.

\section{Use of Established Professional Norms}

As the Court has recognized ever since Strickland, ABA standards and other established professional norms seem a natural benchmark for judging attorney performance. However, in Strickland itself and in many subsequent cases, the Court has hastened to add that "they are only guides" and has given them little or no discernible weight. Williams marked a partial shift in the capital context, and Padilla extended the breakthrough in a noncapital case. As Cullen demonstrates, however, the Court's use of professional norms remains inconsistent even in capital cases.

The inconsistencies may, in part, reflect the peculiarities of habeas. Because the Court cannot, in theory, make new law in habeas cases, the Court has been unable to move decisively beyond Strickland's equivocation on professional norms. Although Williams also remains available as precedent, Williams purported to do no more than apply Strickland, so it has remained easy for the Court to overlook Williams and perpetuate the Strickland approach.

Habeas bypass presents an opportunity to transcend these dynamics. In an appropriate bypass case, the Court can and should expressly repudiate Strickland's equivocation.

Strickland's reservations on professional norms purportedly stemmed from their lack of flexibility: "No particular set of detailed rules for counsel's conduct can satisfactorily take account of the variety of circumstances faced by defense counsel or the range of legitimate decisions regarding how best to represent a criminal defendant." 94 Yet, the ABA Standards are hardly a straitjacket; many are framed in flexible terms, ${ }^{95}$ and those with less flexibility do seem quite basic, general requirements for good legal representation. ${ }^{96}$ And, of course, at least two alternatives were available to address any undue rigidity: the standards could have been made subject to a rebuttable presumption of correctness, or handled through a "selective incorporation" approach, in which individual standards could be given special weight and others discarded as inappropriate for the constitutional analysis.

Strickland's equivocation likely reflects a combination of additional concerns beyond inflexibility, but these do not seem especially weighty today. For instance, Strickland was a capital case, and the majority's analysis may in part reflect the broader efforts of an increasingly conservative Court in the I980s to diminish judicial interference with state administration of the death penalty. Such an agenda, however, seems much less compelling today, in the wake of so many exonerations in the I990s and with many states moving decisively away from capital punishment.

Likewise, Strickland was a habeas case, and may in part reflect the Court's broader efforts to rein in habeas in that time period. Importantly, Teague had not yet been decided, which raised the specter of a flood of new habeas litigation every time the Court adopted an expansive new interpretation of a constitutional right. Now, with Teague's retroactivity rule in place, and-perhaps even more importantly-with the many AEDPA restrictions also on the books, the Court can more freely strengthen constitutional rights without fear that large numbers of convictions will be overturned through habeas.

More generally, hindsight has taught us that there was a fatal flaw in the Strickland Court's strategy to prevent a "proliferation of ineffectiveness challenges." The vague performance standard, intended to discourage ineffectiveness claims, may instead have created, as David Cole puts it, "the worst of all possible outcomes":

Because the standard is fairly open-ended, and does not have the clarity of a "guidelines" approach, it does little to forestall the filing of ineffectiveness claims. And because the Court's standard uncritically accepts the status quo as "effective," it creates no incentive for states to improve on existing standards of legal representation for the poor. ${ }^{97}$

To the extent that the Strickland Court feared giving windfalls to clearly guilty defendants even outside habeas, that concern should be allayed by the prejudice prong. Perhaps the Court lacked confidence back in I984 that lower courts would take seriously the limitations of the prejudice prong. If so, nearly three decades of experience should lay those concerns to rest; there is no evidence that lower courts have been anything approaching profligate in awarding relief on ineffective assistance claims. ${ }^{98}$

In setting forth the ineffectiveness standards in I984, the Court was embarking on what was, for it, uncharted waters. In that context, it is understandable that the Court would have found attractive a deferential, go-slow, case-bycase approach. Now, however, the Court has a great deal of experience with adjudicating ineffective assistance claims. For the Court to continue to adhere to a fact-intensive, casespecific mode of analysis leaves the lower courts without clear guidance for no good reason. The result is seemingly arbitrary differences in the treatment of cases, and a failure to establish any real accountability for lawyers - and, for 
that matter, the states who systematically underfund indigent defense-when legal representation violates established, straightforward, commonsensical practice norms.

The most recent habeas-bypass cases, Padilla and Frye, point to the way out of the current mess. The Court's next step should be to make explicit what is implicit in Padilla and Frye: that the Court has moved beyond Strickland's equivocation (at least when it is not shackled to Strickland by $\left.\int 2254(\mathrm{~d})(\mathrm{I})\right)$, and the lower courts should follow suit.

\section{Conclusion}

I have developed something of a contrarian argument in this article. Whereas the conventional wisdom sees the AEDPA as a disaster for defendants, I suggest that the statute may instead free the Court to adopt more robust interpretations of constitutional rights in habeas-bypass cases. The Court has long had deep reservations about habeas, and not without good reason. The AEDPA, however, gives the Court more freedom to expand constitutional rights without fear of unleashing a torrent of new habeas claims and throwing open the prison doors to large numbers of guilty, dangerous inmates. ${ }^{99}$

There is perhaps no more important area for the Court to take advantage of this "freedom" than in the field of ineffective assistance, particularly as it relates to plea bargaining. With few cases going to trial any more, and with judge and jury unable to do much to protect defendants when there is no trial, effective representation by defense counsel in preparation for and during plea bargaining may be the linchpin to the fairness and reliability of the entire criminal-justice system.

Whether the Court will move forward in this area is uncertain: Padilla, Frye, and Lafler contain plenty of equivocations of their own. Exorcising Strickland's ghost is an important next step, but even that would hardly ensure meaningful accountability for incompetent lawyers and stingy states. The Court will likely require continued prodding, for instance, to tighten up the weak remedy standards sketched in Lafler. In all of this, as I suggested at the outset, state courts and state postconviction counsel may have an especially important role to play-all the more so to the extent that the lower federal courts are being effectively sidelined by the AEDPA.

\section{Notes}

* I am grateful to David Behm for helpful research assistance.

$1 \quad$ Lafler v. Cooper, 132 S. Ct. 1376 (2012); Missouri v. Frye, 132 S. Ct. 1399 (2012); Padilla v. Kentucky, 130 S. Ct. 1473 (2010).

2 Cullen v. Pinholster, 131 S. Ct. 1388 (2011); Harrington v. Richter, 131 S. Ct. 770 (2011); Premo v. Moore, 131 S. Ct. 733 (2011).

3 Williams v. Taylor, 529 U.S. 362 (2000).

4 For background on the development of these standards and their role in Sixth Amendment jurisprudence, see Margaret Colgate Love, Evolving Standards of Reasonableness: The ABA Standards and the Right to Counsel in Plea Negotiations, 39 Fordham Urban L.J. 147 (2011).

5 Strickland v. Washington, 466 U.S. 668 (1984).
6 Id. at 688

7 Id. at 694

8 Id. at 689

9 Id. at 690.

10 Id. at 688-89.

11 Id. at 699.

12 Id. at 690.

13 If trial counsel continued to represent the defendant on appeal, there obviously could not be an ineffective assistance claim in the direct review process. Even if a new lawyer came on board for an appeal, that lawyer might be reluctant for any number of reasons to attack trial counsel's performance, and in any event, a number of jurisdictions decided that ineffective assistance claims should be brought in the first instance in the trial court after direct review was concluded.

14 Wainwright v. Sykes, 433 U.S. 72, 90 (1977).

15 See, e.g., id.; Stone v. Powell, 428 U.S. 465 (1976); Rose v. Lundy, 455 U.S. 509 (1982).

16 Lockhart v. Fretwell, 506 U.S. 364 (1993).

17 Id. at 369-70.

18 For some general reflections on this statute and its impact, see Michael M. O'Hear, Not So Sweet: Questions Raised by Sixteen Years of the PLRA and AEDPA, 24 Fed. Sent'g Rep. 223 (2012).

19 In the five years prior to 1984 , when Strickland was decided, there were only nine exonerations from death row; in the five years prior to 2000, when Williams was decided, there were twenty-eight exonerations. Then, in 2000 alone, there were an additional nine, which was the highest number up to that point in time in the modern era of the death penalty. These numbers come from the website of the Death Penalty Information Center: http://www.deathpenaltyinfo.org/innocence-and-deathpenalty, "Exonerations by Year" (table).

20 Bell v. Cone, 535 U.S. 685, 718 n.17 (2002) (Stevens, J., dissenting) (quoting Charles Lane, O'Connor Expresses Death Penalty Doubt; Justice Says Innocent May Be Killed, Washington Post, July 4, 2001, at A1).

21 Stephen Smith has offered a similar account of Williams as marking a "dramatic shift" in the Court's approach to ineffec. tive assistance, which he also connects to O'Connor's reserva. tions about the death penalty. Taking Strickland Claims Seriously, 93 Marq. L. Rev. 515, 517, 536 n.78 (2009).

22 Williams, 529 U.S. at 391.

23 Id. at 396.

24 Id. at 386-87 (Stevens, J.).

25 Id. at 405-11.

26 Id. at 411.

27 Glover v. United States, 531 U.S. 198 (2001).

28 Id. at 204

29 The Court had made this point in Strickland itself. 466 U.S. at 686 ("We need not consider the role of counsel in an ordinary sentencing, which may involve informal proceedings and stan. dardless discretion in the sentencer and hence may require a different approach to the definition of constitutionally effec. tive assistance. A capital sentencing proceeding like the one involved in this case, however, is sufficiently like a trial in its adversarial format and in the existence of standards of decision that counsel's role in the proceeding is comparable to counsel's role at trial ...." (citations omitted)).

30 Glover, 531 U.S. at 204

31 My discussion of Williams and its progeny presents these decisions-and particularly the views of O'Connor and Kennedy, who seem to be the key figures in this line of casesas responsive to a variety of concerns that are specific to the criminal justice system, e.g., concerns regarding habeas cor. pus and death row exonerations. The cases may be seen more generally, however, as an expression of what Cass Sunstein calls "judicial minimalism." According to Sunstein, minimalist judges "seek to avoid broad rules and abstract theories, and 
attempt to focus their attention only on what is necessary to decide particular cases. Minimalists emphatically believe in reason-giving, but they do not like to work deductively; they do not see outcomes as reflecting rules or theories laid down in advance. They also tend to think analogically and by close ref. erence to actual and hypothetical cases." Cass Sunstein, Forward: Leaving Things Undecided, 110 Harv. L. Rev. 4, 14 (1996). Sunstein characterizes both O'Connor and Kennedy as minimalists.

32 Knowles v. Mirzayance, 556 U.S. 111 (2009); Holland v. Jackson, 542 U.S. 649 (2004); Yarborough v. Gentry, 540 U.S. 1 (2003) These are the cases in which the Court reached the merits of an ineffective assistance claim (within the constraints of $\S 2254(d)(1))$. There were a number of other cases presenting ineffective assistance issues in which the Court did not reach the merits. See, e.g., Bell v. Thompson, 545 U.S. 794 (2005)(holding that the court of appeals abused its discretion in staying mandate).

33 Bell v. Cone, 535 U.S. 685 (2002).

34 Id. at 694

35 Id. at 701

36 Woodford v. Visciotti, 537 U.S. 19 (2002).

37 Wiggins v. Smith, 539 U.S. 510 (2003).

38 Id. at 522.

39 Id. at 524-25.

40 Id. at 537-38.

41 ld. at 522

42 Rompilla v. Beard, 545 U.S. 374 (2005).

43 Porter v. McCollum, 130 S. Ct. 447 (2009).

44 Schriro v. Landrigan, 550 U.S. 465 (2007)

45 Bobby v. Van Hook, 130 S. Ct. 13 (2009).

46 Wong v. Belmontes, 130 S. Ct. 383 (2009). Capital defendants also lost in Bradshaw v. Richey, 546 U.S. 1146 (2005), and Florida v. Nixon, 543 U.S. 175 (2004), although these cases did not involve mitigation issues.

47 Padilla v. Kennedy, 130 S. Ct. 1473 (2010).

48 Id. at $1482-83$.

49 Frye, 132 S. Ct. 1399 (2012).

50 Id. at 1408.

51 Lafter, 132 S. Ct. 1376 (2012).

52 Atkins v. Virginia, 536 U.S. 304 (2002).

53 Roper v. Simmons, 543 U.S. 551 (2005).

54 Ewing v. California, 538 U.S. 11 (2003); Lockyer v. Andrade, 538 U.S. 63 (2003).

55 Graham v. Florida, 130 S. Ct. 2011 (2010).

56 Michael M. O'Hear, The Beginning of the End for Life Without Parole?, 23 Fed. Sent'g Rep. 1, 2 (2010).

57 The jurisprudential contest between an open, evolutionary system and a closed, rigid system has played out most openly and heatedly in the Eighth Amendment cases. However, it has also sometimes appeared in the Sixth Amendment context. See, e.g., Bobby v. Van Hook, 130 S. Ct. 13, 20 (2009) (Alito, J., concurring) ("It is the responsibility of the courts to determine the nature of the work that a defense attorney must do in a capital case in order to meet the obligations imposed by the Constitution, and I see no reason why the ABA Guidelines should be given a privileged position in making that determination.").

58 Relevant portions were reprinted at 16 Fed. Sent'g Rep. 126 (2003).

59 See, e.g., id. at 128 ("It is a grave mistake to retain a policy just because a court finds it constitutional.").

60 ld. at $127-28$

61 Consistent with this view that Kennedy has particular concerns with inflexible punishment are his votes in a recent series of cases that have adopted narrowing interpretations of federal mandatory minimum statutes. These are discussed in Michael M. O'Hear, Mandatory Minimums: Don't Give Up on the Court, 32 Cardozo L. Rev. De Novo 67, 80-89 (2011).
62 Tracy L. Snell, U.S Dep't of Justice, Capital Punishment, 2010_statistical Tables 13 (2011).

63 Id. at 18.

64 Miller v. Alabama, 567 U.S. _ (2012).

65 Brown v. Plata, 131 S. Ct. 1910 (2011)

66 Harrington v. Richter, 131 S. Ct. 770 (2011).

67 Id. at 780.

68 Id. at 786 (quotation marks and internal citation omitted).

69 ld. at 784

70 Knowles v. Mirzayance, 129 S. Ct. 1411 (2009).

71 Id. at 786-87 (citations omitted).

72 Williams, 529 U.S. at 409 (rejecting Fourth Circuit test for $\S 2254(d)(1)$, which precluded habeas relief unless the state court had applied federal law "in a manner that reasonable jurists would all agree is unreasonable").

73 ld. at 788 (quoting Knowles)

74 Id. (citing Knowles).

75 Id. at 786 (quoting Yarborough v. Alvarado, 541 U.S. 652, 664 (2004)).

76 Premo, 131 S. Ct. at 739-40 (2011).

77 Id. at 741-42 ("In determining how searching and exacting their review must be, habeas courts must respect their limited role in determining whether there was manifest deficiency in light of information then available to counsel. AEDPA com. pounds the imperative of judicial caution.")

78 Cullen v. Pinholster, 131 S. Ct. 1388 (2011).

79 ld. at 1398.

80 Id. at 1406-07.

81 Id. at 1427-28 (Sotomayor, J., dissenting).

82 Id. at 1407.

83 Id. at 1390.

84 | borrow this insightful point from Nancy J. King, Lafler v. Cooper and AEDPA, 122 Yale L.J. Online 29 (2012), http:// yalelawjournal.org/2012/06/19/king.html.

85 Padilla, 130 S. Ct. at 1487.

86 Frye, 132 S. Ct. 1409.

87 Lafler, 132 S. Ct. at 1388-89 (citations and internal quotation marks omitted).

88 ld. at 1389.

89 Id.

90 ld.

91 See Larry Yackle, AEDPA Mea Culpa, 24 Fed. Sent'g Rep. 329 (2012).

92 Teague v. Lane, 489 U.S. 288 (1989).

93 Nancy J. King, Non-Capital Habeas Cases After Appellate Review: An Empirical Analysis, 24 Fed. Sent'g Rep. 308, 317 (2012).

94 Strickland, 466 U.S. at 688-89.

95 See, e.g., American Bar Ass'n, ABA Standards For Criminal Justice: Defense Function std. 4.3 .2 (3d ed. 1993) ("As soon as practicable, defense counsel should seek to determine all relevant facts known to the accused." (emphasis added)).

96 See, e.g., id. std. 4-4.1 ("Defense counsel should conduct a prompt investigation of the circumstances of the case and explore all avenues leading to facts relevant to the merits of the case and the penalty in the event of conviction.").

97 David Cole, Gideon v. Wainwright and Strickland v. Washington: Broken Promises, in Criminal Procedure Stories 101, 114 (Carol S. Steiker ed., 2006).

98 See id. at 117 (discussing data from California and Fifth Circuit courts).

99 To be clear, although I think that some aspects of AEDPA may have some positive effects, my overall view of AEDPA remains that it has made federal habeas law unnecessarily complex and restrictive. See O'Hear, supra note 18. Stronger deference principles could have been introduced into habeas law without creating the byzantine mess that is AEDPA. 